\title{
Illustrating the way to harmony amid wildlife and agriculture near sivalik mountain range of northern India: an empirical
}

\begin{abstract}
This study is the first attempt of its kind with the following two objectives viz., to study the success story cum case study of an academician turned assiduous farmer, and to enlist and rank the explicit benefit gained by the villagers due to his intervention and presence. Out of 3 districts in sub-mountainous region, one district, block and village named Ropar, Nurpur bedi and Bathlour Khad were randomly selected respectively and the case of was found in serendipity. 4 broad methodological steps were followed to do case study and to rank the explicit benefit 'sum of rank method' was followed. Three major orchard plantations were Kinnow, Lemon and Eucalyptus. Three major challenges viz., sustainable installation of submersible pump, protect the fruits from wild animals, avian and insects; and marketing of the farm produce from the remote village were resolved up to fine extent. But still, Monkeys and Porcupines are responsible for the production loss in Kinnow orchard. The manuscript covers classical example of evolution of ecosystem vis-à-vis Porcupine in the Sivalik mountain range of northern India. Benefit: cost ratio from Kinnow farm was 2.025. To quantify the benefits gained by the villages 12 respondents were taken randomly. 'Technical advice regarding installation of submersible pumps $(\mathrm{W}=29)$ ' was rated as most important benefit by the respondents. The findings in the present manuscript generated quantitative as well as qualitative scientific output for policy-makers, planners and implementers that would guide them toward betterment of the region.
\end{abstract}

Volume 3 Issue 2 - 2018

\section{Sudhanand Prasad Lal, Sujeet Kumar Jha Division of Dairy Extension, Indian Council of Agricultural Research-National Dairy Research Institute, India}

Correspondence: Sudhanand Prasad Lal, Division of Dairy Extension, ICAR-National Dairy Research Institute, PO Box I3200I, Haryana, India, Tel 078768908 I0, Email sudhanandlalI00@gmail.com

Received: December 30, 2017 | Published: April 12, 2018

Keywords: case study, ecological sustainability, green revolution belt, humanwildlife conflict, punjab, sivalik mountain, success story, sustainable agriculture

\section{Introduction}

Farmers in India and overseas face serious threats from pests, natural calamities, ${ }^{2-7}$ spoilage by animals ${ }^{8}$ and other various types of crop losses, resulting in yield loss. ${ }^{1}$ When one consider about farming near mountain range, it encompasses a lot of challenges viz., irrigation, wild animals and marketing of produce. Sivalik sub-Himalayan range of the northern Indian subcontinent extends for more than $1600 \mathrm{~km}$ with width of only $16 \mathrm{~km}$, having an average elevation of 3000-4000 feet. ${ }^{9}$ In this background, the present research was undertaken with the following two objectives:

i) To study the success story cum case study of a retired principal turned assiduous farmer is discussed by an empirical inquiry

ii) To enlist and rank the explicit benefit gained by the villagers due to his intervention and presence.

\section{Materials and methods}

\section{Study area}

India is divided into 15 agro-climatic regions and out of which trans-Gangetic plain region was selected for the present investigation. Only one state of India comes under trans-Gangetic plain region i.e. Punjab. On the basis of agro-climatic conditions, the state has been divided into 3 zones and of which the sub-mountainous region (Zone III) was selected. Out $\mathrm{f} 3$ districts in sub-mountainous region, one district, block and village named Ropar, Nurpur bedi and Bathlour Khad were randomly selected respectively (Figure 1).

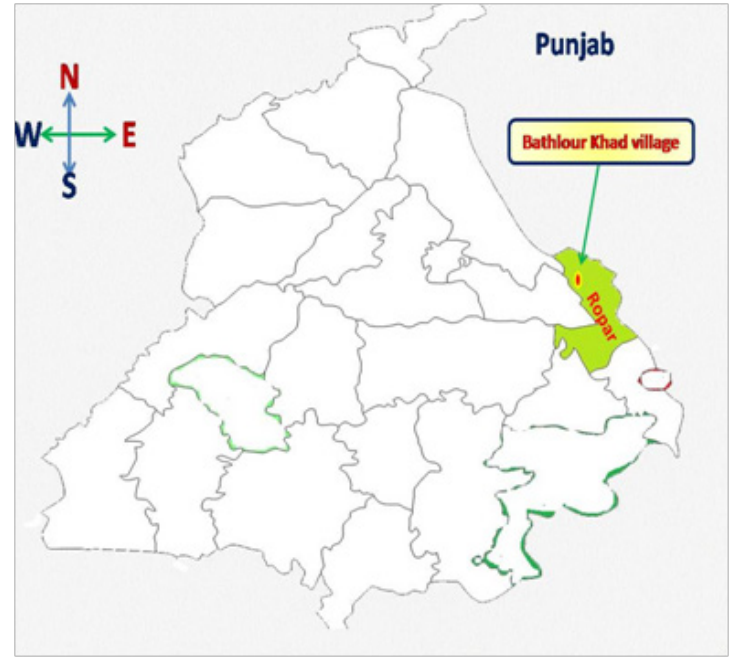

Figure I Map showing the location of the research area.

\section{Data collection tool}

The study is divided into two parts the case study of a retired principal turned assiduous farmer named Dr. Daya Singh Dhaliwal (Ph.D. Botany; Retired Principal Kalsa College, Patiala) and the explicit benefit gained by villages due to his intervention and presence. It was hypothesized that no explicit benefit was gained by villages due to his intervention and presence. Primary data can be collected through 
observation, interview schedule and case study method. For the indepth analysis of the success story of Dr. Dhaliwal, the case study methodology was used. It is an empirical inquiry that investigates a contemporary phenomenon in its natural settings. ${ }^{10,11}$ Primary objective of case study is exploratory, primary data qualitative and design is flexible in nature. ${ }^{12}$ Case study methodology was recently used among adopters and non-adopters of improved dairy practices in Ethiopia. ${ }^{13}$ There are 4 broad steps in conducting a case study ${ }^{11,14}$ explained in Figure 2.

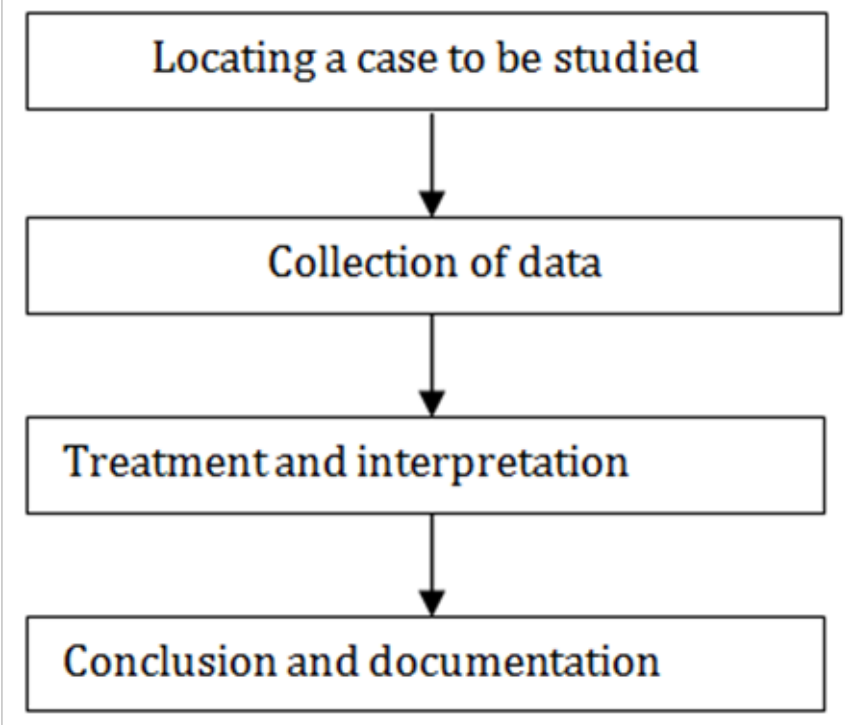

Figure 2 Four broad steps of case study.

Interview schedule method is widely adopted primary data collection tool ${ }^{2-7}$ and was used to figure out and prioritize the benefits gained by the intervention. Benefits analysis is common in extension study to know the results of any intervention. The ranking procedure followed may be different for measuring perceived benefits viz., Garrett's ranking method, ${ }^{6,15}$ mean score ranking procedure, ${ }^{4}$ and Alfares ranking procedure. ${ }^{3,16}$ To determine the ranking in Alfares model least-squares regression was applied to $S_{n}$ versus $n$ :

$$
\mathrm{S}_{\mathrm{n}}=3.19514+\frac{37.75756}{\mathrm{n}}
$$

Therefore, for any set of $\mathrm{n}$ ranked benefits (in the present manuscript $\mathrm{n}$ represents 4 benefits), assuming a weight of 100 percent for the first-ranked benefit, the percentage weight of benefits ranked as $r$ is given by:

$$
\begin{aligned}
& W r, n=100-S_{n}(r-1), \text { or } \\
& W r, n=100-(3.19514+37.75756 / n)(r-1), 1 \leq r \leq n, r
\end{aligned}
$$

and $\mathrm{n}$ are integer

Analysis can be done through the sophisticated statistical tool viz., Principal Component Analysis ${ }^{17,18}$ exploratory factor analysis, ${ }^{6,19}$ Standardized Multivariate Regression Analysis ${ }^{17}$ and Polytomous Universal Model. ${ }^{7}$ But, for the present investigation the simplest method i.e. 'sum of rank method' was followed in which the rank given by the respondents were summed up and to obtain the respective weights (W) the summed up score was subtracted with the maximum possible summed up score; and in the present study it was 48 .

\section{Results and discussion}

The present case study is based on the success story of a single individual, rather than a family, group, community, institution or an organization. So, the Profile of the subject under investigation is given in Table 1. The quest of farming by Dr. Daya Singh Dhaliwal began just before the retirement from the post of principal. He purchased 32.5 acre land in the remotest village of Punjab named Bathlour Khad. It would be worth mentioning that Punjab was the leading state in ushering 'green revolution' in India. In 17.5 acre land, natural vegetation was allowed to grow and in rest 15 acre orchard was established (Table 2). Kinnow was developed by Howard B. Frost in 1915, at the University of California and released for commercial cultivation in $1935^{20}$ but, the tree has a strong tendency to alternate bearing. There were three major challenges in front of Dr. Dhaliwal to sustainably establish and continue the orchards viz., installation of submersible pump (Figure 3A), protect the fruits from wild animals, avian and insects (Figure 3B); and marketing of the farm produce from the remote village (Figure $3 \mathrm{C}$ ). All three problems were almost resolved by his grit and determination. Submersible pump was successfully installed by team of experts and by far it is working in a good condition. Modified unidirectional electronic ultrasonic animal repeller was made to repel the animals as human can't feel and get disturbed due to Ultrasonic waves but it is a repelling alarm hooter for the animals (Figure 4A-4C). The direction of electronic ultrasonic animal repeller is towards the Sivalik range, where the animals resided. Following a transect walk ${ }^{21}$ (a type of Participatory Research Methods) across the landscape of Sivalik mountain range of northern India, following Wildlife and Avian were located (Table 3).

Table I Profile of the case under investigation

\begin{tabular}{ll} 
Country & India \\
\hline Agro-climatic region & Trans-Gangetic plain region \\
State & Punjab \\
Zone & Sub-mountainous (Zone III) \\
District & Ropar \\
Block & Nurpur bedi \\
Village & Bathlour Khad \\
Interaction & Agriculture and wildlife \\
Case-study subject & Dr. Daya Singh Dhaliwal \\
Education & Ph.D. Botany \\
Date of Birth & 30 th April I 948 \\
Present Age & 69 years and 8 months \\
Nickname & Mountain man of farming \\
Past profession & Retired Principal \\
Present occupation & Farming \\
Orchard established & 2006 AD \\
Land-owned & 32.5 acre \\
Natural vegetation in & I7.5 acre \\
Orchard area & I5 acre \\
\hline
\end{tabular}

Table 2 Major plantation in the orchard

\begin{tabular}{lll}
\hline Family Names & Scientific Names & $\begin{array}{l}\text { Common } \\
\text { Names }\end{array}$ \\
\hline $\begin{array}{l}\text { Hybrid of two citrus } \\
\text { cultivars }\end{array}$ & $\begin{array}{l}\text { Citrus nobilis } \times \\
\text { Citrus deliciousz }\end{array}$ & Kinnow \\
Rutaceae & Citrus limon & Lemon \\
Myrtaceae & Eucalyptus globulus & Eucalyptus \\
\hline
\end{tabular}


But, even after tireless efforts of Dr. Dhaliwal, few Monkeys jump into the boundaries of the orchard to eat the Kinnow fruits; while Porcupines (a Porcupine is rodentian with sharp spines to protect against predators but has become pest for Kinnow farming) dug their holes below the boundaries of the orchard in order to enter the campus. It would be interesting to mention here that initially Porcupine were unable to figure out Kinnow is an eatable but in due course of time it discovered fruits palatable value. It was the classical example of evolution of ecosystem in the Sivalik mountain range of northern India. So, presently only 2 wildlife viz., Monkey (Figure 4B \& 4D) and Porcupine is responsible for the production loss of the orchards but the loss is at the threshold limits. For season long control of fruit fly 5 traps/acre in Kinnow orchard was used but the condition was that traps should be cleaned periodically (Table 3). Swamp deer and wild swine can't enter the orchard now due to electric wire fencing; the alternate current is kept up to the level of just giving minor shock to the animals and now these animals is well acquainted with this phenomenon and so they don't come close to the boundary of the orchard. Subject has made a small pond like system just outside the boundary of the orchard (Figure 4E \& 4F) for swamp deer so that they can drink water and recreate there and even undersized kinnow is kept near the pond for their feeding. In rainy season water is automatically filled in the pond as it is situated near the mountain foothills, while in the summer the subject filled the water through the submersible

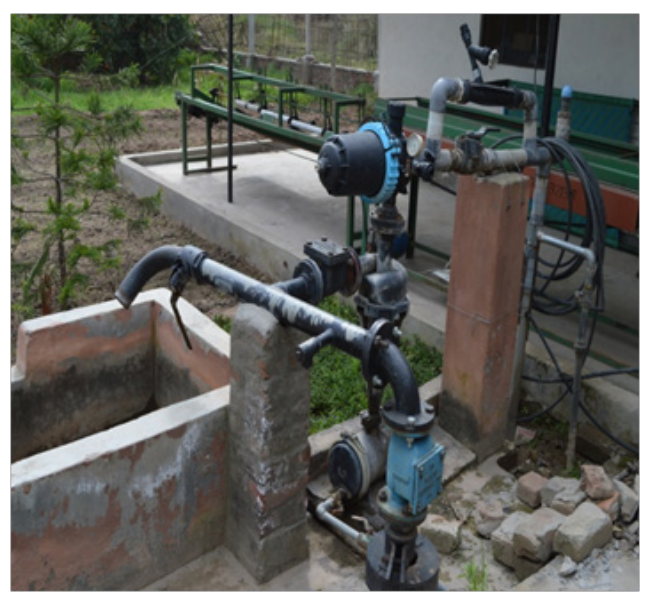

Figure 3 Challenges and solutions, Figure 3(A) Installed submersible pump (bore at 150 feet)

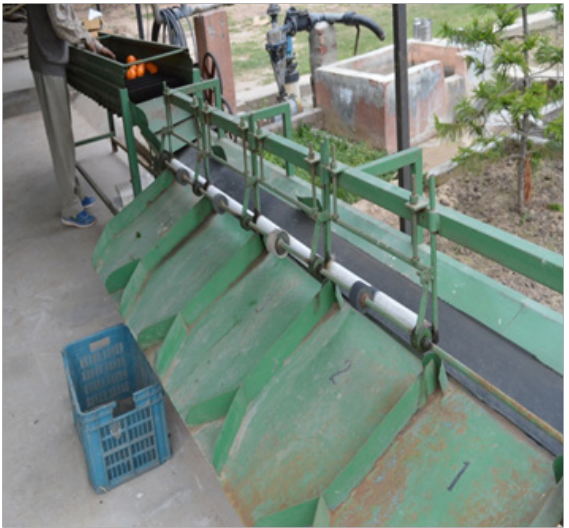

Figure 3(C) Kinnow Grading Machine for marketing. pump. 4-5 barking deer lives inside the campus as it is not the pest for the kinnow crop and it only the grasses. ${ }^{22}$ Peafowl lives inside the orchard and eat only negligible proportion of production (Figure 4A). Red jungle fowl fed on insects and it has multiplied its number due to new ecosystem. To solve the problem of marketing for the remote village 'Kinnow Grading Machine' was purchase by the subject. It is marked 5 to 1 ( 5 for oversized kinnow and 1 for the smallest size; while the best marketable size is of grade 4 , and 2 and 1 is used by the Juice shop.

Table 3 Major Wildlife and Avian located during transect walk

\begin{tabular}{lll}
\hline Order Names & Scientific Names & Common Names \\
\hline Primates & Rhesus macaque & Monkey \\
Rodentia & Hystrix indicus & Porcupine \\
Artiodactyla & Rucervus duvaucelii & Swamp deer \\
Artiodactyla & Sus scrofa & Wild swine \\
Artiodactyla & Muntiacus muntjak & Barking deer \\
Galliformes & Pavo cristatus & Peafowl \\
Galliformes & Gallus gallus & Red junglefowl \\
Diptera & Drosophila & Fruit fly \\
\hline
\end{tabular}

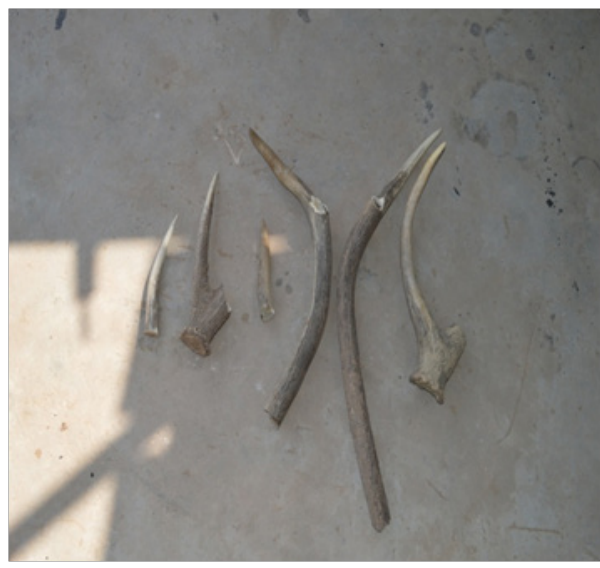

Figure 3(B) Tines of Rucervus duvaucelii.

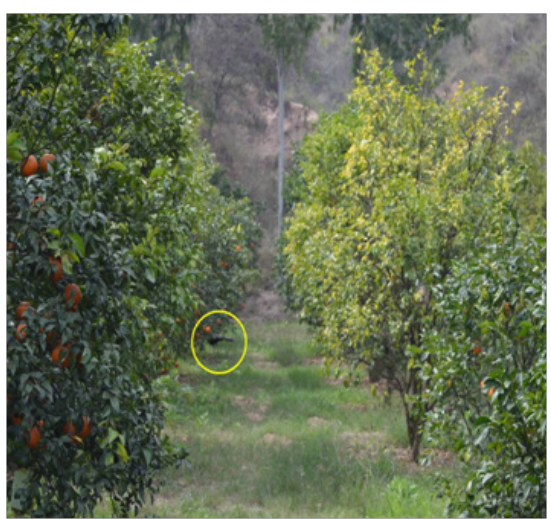

Figure 4 Facets of intervention adopted in the orchard near Sivalik Mountain range, 4(A) Pavo cristatus in the Kinnow orchard. 


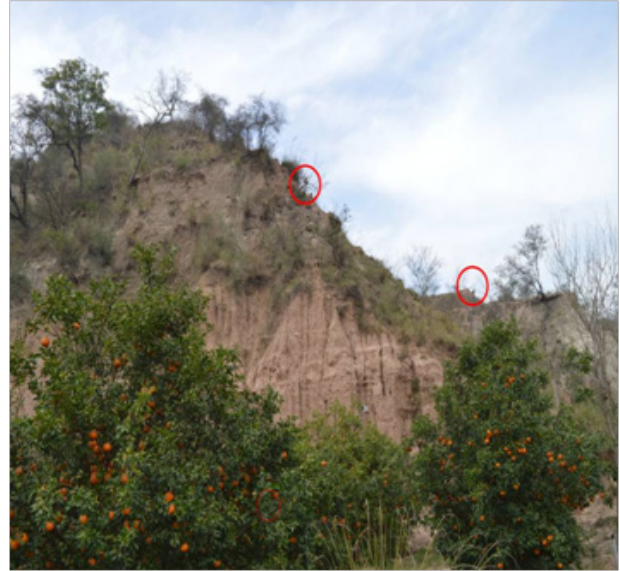

Figure 4(B) Rhesus macaque (encircled), outside the orchard.

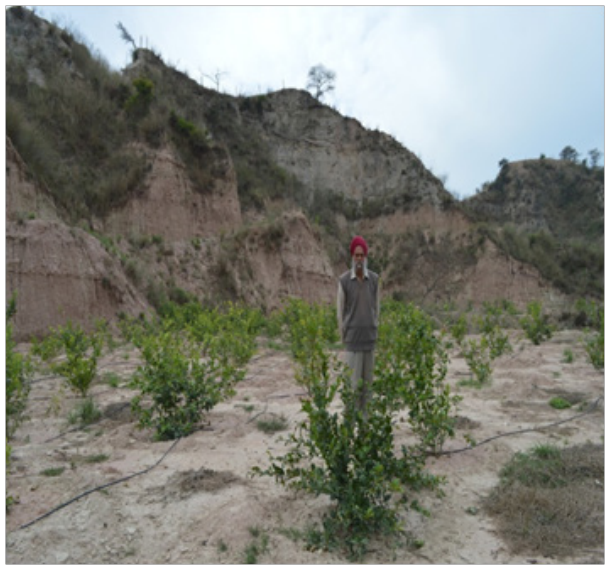

Figure 4(D) Lemon plantation with drip fustigation system.

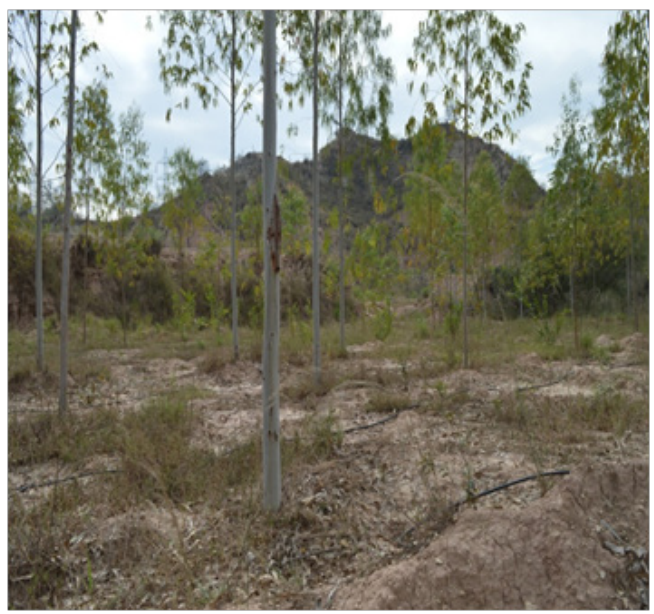

Figure 4(F) Eucalyptus plantation near Sivalik.

\section{Economics analysis of kinnow cultivation}

Orchard has a huge potential to promote family farming. ${ }^{23}$ Initially 1500 kinnow trees were planted but only 1350 survived due to Phytophthora rot of Kinnow and several other reasons. Although trees were replanted at the place of dead tree but presently only 1350 trees are

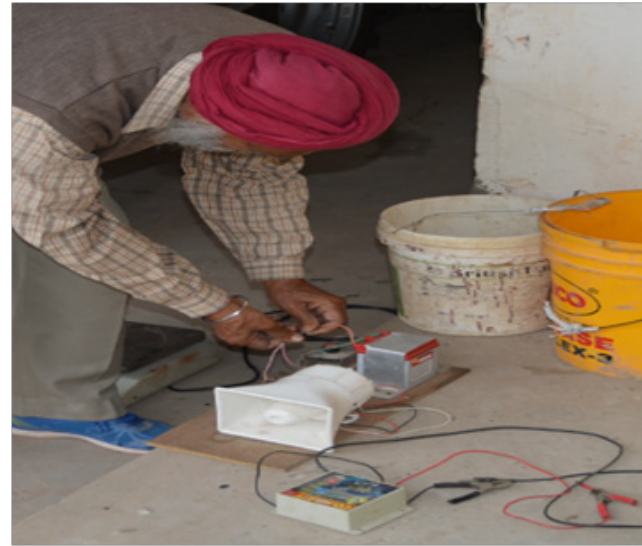

Figure 4(C) Modified ultrasonic animal repeller.

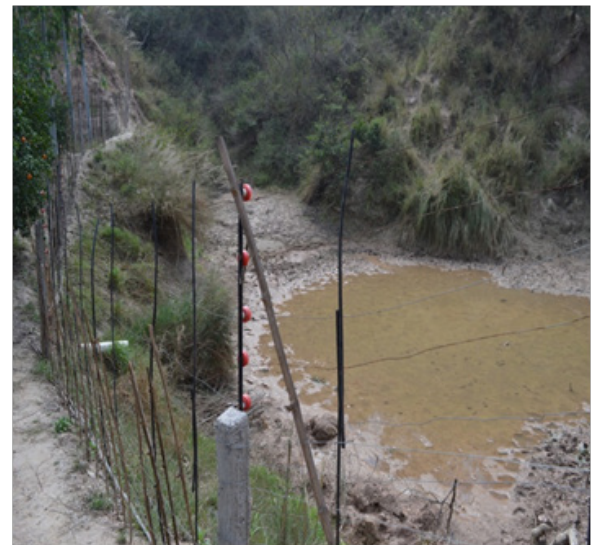

Figure 4(E) Rucervus duvaucelii recreation spot.

fruit bearing. One season gross income in Rs. (1350 tree*50kg*Rs.30/ $\mathrm{kg}=$ Rs. 2025000) and gross return consider alternate bearing was Rs. 1012500. Kinnow is sold at the end of the season during March to fetch more profit. 50q yield was destroyed by wild animals including Monkey and Porcupine. Doing all the computation Benefit: cost was 2.025 (Table 4).

\section{Explicit benefit gained by the villagers due to the intervention of mountain man}

Subject was popularly known as mountain man of farming (more precisely, mountain man of kinnow farming). To quantify the benefits gained by the villages 12 respondents were taken. Among all the benefits presented in Table 5 'technical advice regarding installation of submersible pumps $(\mathrm{W}=29)$ ' was rated as most important benefit by the respondents. He taught villages that successful and sustainable bore is possible in village and made bore at 150 feet. Due to his guidance 15 new bores were installed in village and now few farmers have started paddy cultivation also. 'Control and management of wild animals to protect the farm crops $(\mathrm{W}=24)$ ' was rated as second most important benefit by the respondents. This was due to the fact that wild animals had become pest for many agricultural crops in the study locale but due following his footprints many farmers has now evaded the problems up to fine extent. 'Suggestions gained vis-à-vis plantation of Kinnow, Lemon and Eucalyptus (W=13)' was ranked 
third important benefit by the respondents. Few farmers have stated the cultivation of these crops. 'Guidance regarding sale of farm produce in order to fetch fair and remunerative price' $(\mathrm{W}=6)$ " was ranked as the forth important benefit by the respondents as few farmers had learnt the marketing knack from the mountain man (Table 5).

Table 4 Economics of kinnow cultivation in 2017 yield year

\begin{tabular}{ll}
\hline Number of kinnow tree planted & $\mathbf{I 5 0 0}$ \\
\hline Fruits giving tree & 1350 \\
Production (kg/plant) & 50 \\
Total production in kg (I350*50) & 67500 \\
Loss due to wild animals and others (in kg) & 5000 \\
March Ist week price per kg & $@$ Rs 30 \\
Gross return (in Rs. I350*50*30) & 2025000 \\
Gross return consider alternate bearing & 1012500 \\
Permanent employment (number of person) & 3 \\
Seasonal employment (December-March) & 32 \\
Maximum yearly expenditure for the orchards & 500000 \\
Benefit: cost (Return on investment) & 2.025 \\
\hline
\end{tabular}

Table 5 Ranking pattern of benefits gained by respondents $(n=12)$

\begin{tabular}{lllll}
\hline SN & Benefits & Sr & W & Rank \\
\hline I & $\begin{array}{l}\text { Technical advice regarding installation of } \\
\text { submersible pumps }\end{array}$ & 19 & 29 & I \\
2 & $\begin{array}{l}\text { Control and management of wild animals } \\
\text { to protect the farm crops }\end{array}$ & 24 & 24 & II \\
3 & $\begin{array}{l}\text { Suggestions gained vis-à-vis plantation of } \\
\text { Kinnow, Lemon and Eucalyptus } \\
\text { Guidance regarding sale of farm produce } \\
\text { in order to fetch fair and remunerative } \\
\text { price }\end{array}$ & 45 & 13 & III \\
& & 6 & IV \\
\hline
\end{tabular}

Note: $S R=$ Sum of rank; for 12 respondents and 4 statements, the range could be from I2-48 for SR;W=Weightage

\section{Conclusion}

The study examined the contribution of the Dr. Daya Singh Dhaliwal with the following two objectives viz., to study the success story cum case study of him, and to enlist and rank the explicit benefit gained by the villagers due to his intervention and presence. Out of 3 districts in sub-mountainous region, one district, block and village named Ropar, Nurpur bedi and Bathlour Khad were randomly selected respectively and the case of was found in serendipity. 4 broad methodological steps were followed to do case study and to rank the explicit benefit 'sum of rank method' was followed. Three major orchard plantations were Kinnow, Lemon and Eucalyptus. Three major challenges viz., sustainable installation of submersible pump, protect the fruits from wild animals, avian and insects; and marketing of the farm produce from the remote village were resolved up to fine extent. But still, Monkeys and Porcupines are responsible for the production loss in Kinnow orchard. The manuscript covers classical example of evolution of ecosystem vis-à-vis Porcupine in the Sivalik mountain range of northern India. Benefit: cost ratio from Kinnow farm was 2.025. To quantify the benefits gained by the villages 12 respondents were taken randomly. 'Technical advice regarding installation of submersible pumps (W=29)' was rated as most important benefit by the respondents. 'Control and management of wild animals to protect the farm crops $(\mathrm{W}=24)$ ' was rated as second most important benefit by the respondents. Thus, future research can be done to investigate the impact of his intervention solely on agricultural crop viz., maize, wheat, rice and other fodder crops.

\section{Acknowledgements}

This manuscript is dedicated to the academician turned farmer Dr. Daya Singh Dhaliwal; who despite being rich and influential (simultaneously being modest and living low profile life) granted me his kind permission and blessings to go ahead for this manuscript.

\section{Conflict of interest}

Authors declare that there are no conflicts of interest.

\section{References}

1. Prabu MJ. An excellent method to ward off wild animals. Chandigarh: The Hindu; 2009.

2. Lal SP, Kadian KS, Jha SK, et al. A resilience scale to measure farmers' suicidal tendencies in national calamity hit region of India. Current World Environment. 2014;9(3):1001-1007.

3. Lal SP, Kadian KS, Jha SK, et al. Change in livestock holdings, adaptation strategies and livelihood security of the farmers affected by national calamity in Bihar, India. Indian Journal of Dairy Science. 2015;68(1):8390.

4. Lal SP, Kadian KS, Kale RB, et al. Friedman based analysis of perceived constraints among dairy farmers affected by national calamity in India. Indian Journal of Dairy Science. 2016;69(6):725-727.

5. Lal SP, Kadian KS, Singh. Assessment of change in habitat and farming patterns during pre and post calamity among farmers affected by national calamity in India. Bhartiya Krishi Anushandhan Patrika. 2016;31(4):277280 .

6. Lal SP, Kadian KS, Wodajo WA, et al. Is that environmental factor affected the distressed farmers' most?!- An Exploratory factor analysis of constraint and amelioration strategies in national calamity hit region of India. Current World Environment. 2016;11(3):859-868.

7. Lal SP, Kadian KS, Wodajo WA. Push and Pull factors of migration amongst livestock rearers distressed by national calamity in India: A Polytomous Universal Model analysis. Indian Journal of Animal Sciences. 2017;87(7):906-911.

8. Lal SP, Jha SK, Sinha. Problems of stray animals and its solution. New dimensions of agriculture vis- à- vis climate change, Seed day and Rabi workshop. India: ICAR- Indian Institute of Wheat and Barley; 2009.

9. The Editors of Encyclopedia Britannica. Siwalik Range. Encyclopedia Britannica Inc; 2017.

10. Yin RK. Case Study Research: Design and Methods. $5^{\text {th }}$ edition. CA: Sage Publications; 2014: 282 p.

11. Ray GL, Mondal S. Research Methods in Social Sciences and Extension Education. $3^{\text {rd }}$ revised and enlarged edn, Kalyani Publishers; 2011. 30 p.

12. Runeson P, Höst M. Guidelines for conducting and reporting case study research in software engineering. Empir Software Eng. 2009;(14):131164

13. Wodajo WA, Ponnusamy K, Lal SP. Divergence of Adoption Decision among Adopters and Non-adopters of Improved Dairy Practices in Ambo District of Oromia, Ethiopia: A Case Study. Journal of Global Communication. 2016;9(2):82-87. 
14. Mulay S, Sabarathanam VE. Research methods in extension education. New Delhi: Manasayan; 1980.

15. Goyal J, Singh K, Tiwari M, et al. Constraints perceived by veterinary surgeons of Haryana. Journal of Communication Studies (Interaction) 2014;32(4):112-117.

16. Lal SP, Kadian KS, Jha SK, et al. A Methodological Pathway to Quantify Livelihood Security of the Farmers: A Confluence of Alfares and FAO Approach to Frame an Index. Indian Journal of Economics and Development. 2017;13(2a):772-778.

17. Lal SP, Mohammad A, Ponnusamy K, et al. Expectation of participants in national dairy fair of India: A complete itemization by multivariate analysis. Indian Journal of Animal Science. 2016; 86(8):940-946.

18. Lal SP, Mohammad A, Ponnusamy K, et al. A methodological pathway to quantify perception of the participants in animal fairs with relevance to national dairy mela at NDRI, India. Journal of Animal Research. 2016;6(3):437-444.
19. Patel D, Devi MCA, Lal SP, et al. Variables predicting the role performance of field extension functionaries in animal husbandry sector of Karnataka: A multivariate approach. Indian Journal of Animal Sciences. 2017;87(4):506-511.

20. University of California. Kinnow mandarin hybrid. UCR Citrus Variety Collection; 2017.

21. Tadesse SA, Teketay D. Contribution of the Guassa Community EcoLodge to the Conservation of Wild Mammals, Birds and Woody Plants in Menz-Gera Midir District, North Shewa Administrative Zone, Ethiopia. IJAWB. 2017;2(4):00029.

22. Singh VJ. Wild buzz, the stealth deer. Punjab: Hindustan Times; 2017.

23. Lal SP, Singh SRK, Goyal J, et al. Good Agricultural Practices (GAP) and Good Dairy Farming Practices (GDFP)-A Way Forward to Promote the Family Farming and Attract Rural Youth. In: Choudhary ML, Aditya, editors. Family Farming and Rural Economic Development. 2014:159172. 